\title{
Pengaruh Jarak Tanam dan Dosis Pupuk Kalium Terhadap Pertumbuhan dan Produksi Talas Belitung (Xanthosoma sagittifolium (L.))
}

\section{The effect of Crop Spacing and Potassium Fertilizer Dosage on Growth and Production Blue Taro (Xanthosoma sagittifolium $(\mathbf{L}$.$) )$}

\section{Laila Wati Kristina Lubis dan Suwarto*}

\author{
Departemen Agronomi dan Hortikultura, Fakultas Pertanian, Institut Pertanian Bogor (Bogor Agricultural \\ University), Jl. Meranti, Kampus IPB Darmaga, Bogor 16680, Indonesia \\ Telp.\&Faks. 62-251-8629353 e-mail agronipb@indo.net.id \\ *Penulis untuk korespondensi: wrtskm@yahoo.com
}

Disetujui : 15 Januari 2018 / Published Online 23 Januari 2018

\begin{abstract}
Planting space and dosage of potassium fertilizer are very important in blue taro cultivation. The purpose of this research to understand the influence the planting space and dosage of potassium fertilizer to the growth and production of blue taro. The research has been conducted at the Cikabayan Experimental Station, Department of Agronomy and Horticulture, Bogor Agricultural University, from February until August 2016. A split plot design was usedin this research with three replications. The first factor was the planting space consists of 2 levels $(\mathrm{J} 1=1 \mathrm{~m} \times 1 \mathrm{~m} ; J 2=1 \mathrm{~m} \times 0,5 \mathrm{~m})$ and the second factor is the dosage of potassium fertilizer consists of 2 levels $\left(\mathrm{Kl}=100 \mathrm{~kg} \mathrm{ha}^{-1} \mathrm{KCL} ; \mathrm{K} 2=150 \mathrm{~kg} \mathrm{ha}^{-1} \mathrm{KCL}\right)$. The planting space of $1 \mathrm{~m} \times 1 \mathrm{~m}$ is the best for growth and production of blue taro. The dosage of potassium of fertilizer $150 \mathrm{~kg} \mathrm{ha}^{-1}$ $K C L$ is the best for growth and production of blue taro. The interaction between planting space of $1 \mathrm{~m} \times 1 \mathrm{~m}$ and dosage of fertilizer $100 \mathrm{~kg} \mathrm{ha}^{-1} \mathrm{KCL}$ is the best for growth of blue taro.
\end{abstract}

Keywords: blue taro, distance cropping, fertilizer potassium, growth, production

\section{ABSTRAK}

Jarak tanam dan dosis pupuk kalium yang tepat sangat penting diperhatikan dalam budidaya talas belitung. Penelitian ini bertujuan untuk mengetahui pengaruh jarak tanam dan dosis pupuk kalium terhadap pertumbuhan dan produksi talas belitung. Penelitian dilaksanakan di Kebun Percobaan Cikabayan Atas, Departemen Agronomi dan Hortikultura, Institut Pertanian Bogor, pada bulan Februari sampai Agustus 2016. Rancangan yang digunakan adalah split plot RKLT tiga ulangan. Faktor pertama adalah jarak tanam yang terdiri dari 2 taraf $(\mathrm{JI}=1 \mathrm{~m} \times 1 \mathrm{~m} ; \mathrm{J} 2=1 \mathrm{~m} \times 0,5 \mathrm{~m})$ dan faktor kedua adalah dosis pupuk kalium yang terdiri dari 2 taraf $\left(\mathrm{Kl}=100 \mathrm{~kg} \mathrm{ha}^{-1} \mathrm{KCL} ; \mathrm{K} 2=150 \mathrm{~kg} \mathrm{ha}^{-1} \mathrm{KCL}\right)$. Jarak tanam $1 \mathrm{~m} \times 1 \mathrm{~m}$ merupakan jarak tanam terbaik untuk pertumbuhan dan produksi talas belitung. Dosis pupuk $150 \mathrm{~kg} \mathrm{KCL} \mathrm{ha-1}$ merupakan dosis pupuk terbaik untuk pertumbuhan dan produksi talas belitung. Interaksi perlakuan jarak tanam $1 \mathrm{~m} \times 1 \mathrm{~m}$ dan dosis pupuk $100 \mathrm{~kg} \mathrm{ha}^{-1} \mathrm{KCL}$ terbaik untuk pertumbuhan talas belitung.

Kata kunci: Jarak tanam, pertumbuhan, pupuk kalium, produksi, talas belitung 


\section{PENDAHULUAN}

Talas belitung (Xanthosoma sagittifolium (L.)) merupakan jenis umbi talas-talasan yang mempunyai banyak sebutan seperti kimpul, busil, bote dalam bahasa Indonesia atau blue taro dalam bahasa inggris (Plantamor, 2016). Talas belitung merupakan tanaman tahunan yang mempunyai umbi batang maupun batang palsu yang sebenarnya adalah tangkai daun. Umbi talas belitung biasanya diolah secara sederhana dengan direbus atau digoreng, dan dengan sedikit variasi dapat dibuat produk olahan seperti getuk, keripik, perkedel dan sebagainya (Marinih, 2005). Menurut Badan Ketahanan Pangan Kementerian Pertanian (2015) perkembangan kualitas konsumsi pangan penduduk Indonesia untuk umbi-umbian tahun 2012-2015 mengalami penurunan yaitu $33.9 \mathrm{~g} \mathrm{kapita}^{-1}$ hari $^{-1}, 32.3$ gper kapita $^{-1}$ hari $^{-1}$, dan $31.8 \mathrm{~g} \mathrm{kapita}^{-1}$ hari $^{-1}$. Angka tersebut masih jauh lebih rendah dibandingkan konsumsi padi-padian yang mencapai 295.9 g kapita $^{-1}$ hari $^{-1}$ untuk tahun 2015. Hal tersebut disebabkan pola konsumsi makanan pokok masyarakat Indonesia masih bergantung pada kelompok pangan padi-padian. Kelompok pangan padi-padian yang sering dikonsumsi sehari-hari mengandung energi yang tinggi, namun kurang serat dan dapat meningkatkan kadar glukosa di dalam darah. Hal tersebut berbeda dengan umbiumbian yang juga mengandung karbohidrat dengan energi dan kandungan serat yang tinggi. Akan tetapi umbi-umbian semakin ditinggalkan karena dianggap makanan kurang elit (Corwin, 2007). Umbi talas belitung dapat dikonsumsi sebagai makanan kesehatan untuk makanan diet bagi penderita diabetes melitus.

Umbi talas belitung mempunyai kandungan flavonoid dan saponin yang dapat menurunkan kadar gula darah atau anti diabetes melitus (Nugroho, 2012). Menurut Kay (1973), setiap $100 \mathrm{~g}$ talas belitung mengandung karbohidrat sebesar $23.7 \mathrm{~g}$, lebih rendah dibanding beras $(78.9 \mathrm{~g})$, terigu $(77.3 \mathrm{~g})$ dan jagung kuning (63.6 g). Umbi talas belitung juga mengandung kalsium lebih tinggi sebesar $47 \mathrm{mg}$ dibandingkan beras $(10 \mathrm{mg})$, terigu $(16 \mathrm{mg})$ dan jagung kuning $(9 \mathrm{mg})$. Permasalahan talas belitung saat ini adalah tanaman ini belum banyak diperhatikan dan dimanfaatkan sebagai bahan pangan seperti tanaman pangan lain (Indrasti, 2004). Hal tersebut menyebabkan belum diketahui dengan baik cara budidaya talas belitung, khususnya pada penentuan jarak tanam dan dosis unsur hara yang tepat. Latifa dan Anggarwulan (2009) menyatakan bahwa budidaya talas belitung secara luas merupakan suatu bentuk dukungan terhadap program diversifikasi dan penganekaragaman pangan nasional. Akan tetapi, peningkatkan produktivitas talas belitung belum banyak diperhatikan khususnya mengenai unsur hara yang cukup. Banyaknya manfaat umbi talas belitung seperti yang telah dijabarkan diatas khususnya manfaat untuk penderita diabetes melitus maka perlu ditingkatkan produksi talas belitung. Melalui penelitian ini dengan menggunakan faktor jarak tanam dan dosis pupuk kalium diharapkan diperolej hasil jarak tanam dan dosis pupuk kalium yang tepat, sehingga dapat mengatasi salah satu permasalahan dalam budidaya talas belitung. Jarak tanam dan dosis pupuk kalium yang tepat diharapkan akan menghasilkan pertumbuhan dan produksi yang maksimum pada talas belitung.

\section{METODE PENELITIAN}

Penelitian di lapangan dilaksanakan di Kebun Percobaan Cikabayan Atas, Departemen Agronomi dan Hortikultura, Institut Pertanian Bogor. Penelitian di lapangan hingga analisis tanah dan daun dilaksanakan Februari sampai Agustus 2016. Bahan yang digunakan adalah bibit talas belitung, pupuk N, P, dan K, insektisida dan fungisida. Alat yang digunakan adalah cangkul, kored, pemotong rumput, handtractor, handsprayer, takaran pupuk, timbangan, gunting pangkas, pisau, penggaris, meteran, jangka sorong, amplop, Alat Tulis Kantor (ATK), dan oven. Penelitian dilakukan dengan menggunakan Rancangan Kelompok Lengkap Teracak Petak Terpisah (Split-plot RKLT) dengan 2 faktor dan ulangan sebagai kelompok. Faktor pertama adalah jarak tanam yang terdiri dari 2 taraf $(\mathrm{J} 1=1 \mathrm{~m} \mathrm{x} 1$ $\mathrm{m} ; \mathrm{J} 2=1 \mathrm{~m} \times 0,5 \mathrm{~m}$ ) dan faktor kedua adalah dosis pupuk kalium yang terdiri dari 2 taraf (K1= $100 \mathrm{~kg} \mathrm{ha}^{-1} \mathrm{KCL} ; \mathrm{K} 2=150 \mathrm{~kg} \mathrm{ha}^{-1} \mathrm{KCL}$ ). Terdapat 4 kombinasi perlakuan dengan 3 ulangan sehingga diperoleh 12 satuan percobaan. Apabila perlakuan menunjukkan pengaruh nyata maka dilanjutkan dengan uji DMRT pada taraf 5\%.

Kegiatan pertama yang dilakukan adalah persiapan lahan. Ukuran lahan untuk satu satuan petak percobaan adalah $5 \mathrm{~m} \times 3 \mathrm{~m}$ sehingga luas lahan yang digunakan $180 \mathrm{~m}^{2}$. Pengolahan lahan yang dilakukan meliputi pembersihan gulma, penggemburan tanah, pembuatan guludan dengan panjang guludan $5 \mathrm{~m}$ dan tinggi $30 \mathrm{~cm}$ dan pembuatan lubang tanam sedalam $10 \mathrm{~cm}$. Setiap petak percobaan terdiri dari 3 guludan sehingga terdapat 36 guludan. Penanaman dilakukan dengan meletakkan bibit di dasar lubang tanam 
sebanyak 1 bibit pada setiap lubang tanam. Setiap petak percobaan terdiri dari 15 tanaman untuk jarak tanam $1 \mathrm{~m}$ x $1 \mathrm{~m}$ dan 30 tanaman untuk jarak tanam $1 \mathrm{~m} \times 0.5 \mathrm{~m}$, sehingga terdapat 270 tanaman. Pemeliharaan yang dilakukan adalah pemupukan. Pemupukan dilakukan dengan menggunakan pupuk N, P dan K dengan dosis 100

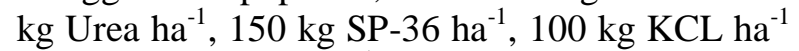
dan $150 \mathrm{~kg} \mathrm{KCL} \mathrm{ha}{ }^{-1}$. Pemupukan dilakukan 2 kali yaitu 1 Minggu Setelah Tanam (MST) dan 2 Bulan Setelah Tanam (BST). Pemupukan pertama dilakukan dengan mengaplikasikan 1/2 dosis pupuk Urea, seluruh dosis pupuk SP-36 dan 1/2 dosis pupuk KCL. Pemupukan kedua dilakukan dengan mengaplikasikan $1 / 2$ dosis pupuk Urea dan 1/2 dosis pupuk KCL. Pemeliharan lain yang dilakukan adalah penyulaman, penyiangan gulma, pembumbunan, pengendalian hama penyakit, pemangkasan daun kuning dan pengambilan anakan. Pemanenan dilakukan pada saat tanaman umur 5 bulan atau 20 MST.

Pengambilan sampel untuk analisis tanah dilakukan pada setiap guludan pada kedalaman 20 $\mathrm{cm}$ dari permukaan tanah. Analisis tanah yang dilakukan meliputi analisis tanah awal dan analisis tanah akhir. Analisis tanah awal dilakukan pada setiap guludan petak percobaan dengan cara mengambil sampel tanah pada kedalaman $20 \mathrm{~cm}$ menggunakan bor tanah. Pengambilan sampel dilakukan sebanyak tiga titik pada 12 petak percobaan secara acak, sehingga total jumlah titik sampel untuk tiga kali ulangan adalah sebanyak 36 titik sampel, lalu dikompositkan dan akan diperoleh 1 buah sampel tanah. Sampel analisis tanah akhir dilakukan pada 4 perlakuan dari setiap masing-masing ulangan, sehingga nanti akan diperoleh 4 buah sampel tanah yang akan dianalisis. Pengambilan sampel dilakukan sebanyak tiga titik pada setiap petak petak percobaan. Jumlah titik sampel untuk 1 perlakuan dari 3 ulangan sebanyak 9 titik sampel, sehingga jumlah titik sampel yang diambil untuk 4 perlakuan sebanyak 36 titik sampel. Sampel tanah tersebut kemudian dikompositkan dan dibersihkan dari sisa-sisa daun dan batang gulma yang terikut.

Analisis kandungan hara daun dilakukan satu kali setelah pemanenan. Analisis kadar hara dalam daun dilakukan untuk mengetahui kondisi status hara $\mathrm{N}, \mathrm{P}$ dan $\mathrm{K}$ dalam daun. Waktu pengambilan sampel daun dilakukan pada pagi hari pukul 07.00 - 09.00 WIB dan tidak dilakukan pada sore hari atau dalam kondisi hujan. Sampel daun yang diambil yaitu daun ke 2 atau ke 3 dari susunan daun paling atas. Pengambilan sampel daun dipisahkan menurut perlakuan dan ulangannya, sehingga akan terdapat 12 sampel daun yang akan dianalisis. Sampel daun kemudian dioven pada suhu $70^{\circ} \mathrm{C}$ selama 24 jam dan dihaluskan menggunakan blender, ditimbang $5 \mathrm{~g}$ dan dimasukkan kedalam wadah plastik zipper yang telah diberi label kemudian dibawa ke laboratorium untuk dianalisis. Parameter yang diamati pada pertumbuhan tanaman yaitu persentase tanaman hidup, diameter batang, tinggi tanaman, jumlah daun hijau dan daun kuning. Pengamatan persentase tanaman hidup dilakukan 1 MST hingga panen sedangkan diameter batang, tinggi tanaman, jumlah daun hijau diamati setelah tanaman berumur 1 BST selanjutnya pengamatan dilakukan setiap minggu hingga panen. Jumlah daun kuning diamati saat 7 MST hingga panen. Parameter yang diamati pada produksi tanaman meliputi jumlah umbi, panjang umbi, diameter umbi, panjang bongkol, diameter bongkol, Berat Basah (BB) umbi, Berat Kering (BK) umbi, BB brangkasan, BK brangkasan, dan indeks panen. Pengamatan dilakukan pada 5 tanaman contoh pada setiap petak percobaan sehingga diperoleh 60 tanaman contoh.

\section{HASIL DAN PEMBAHASAN}

\section{Kondisi umum}

Hasil analisis tanah sebelum penanaman pada bulan Februari 2016 berdasarkan kriteria Balittanah (2009) menunjukkan bahwa sifat kimia tanah $\mathrm{pH}\left(\mathrm{H}_{2} \mathrm{O}\right)$ tergolong masam dengan nilai $\mathrm{pH}$ sebesar 5,32. Menurut Prohati (2016) talas belitung dapat tumbuh dengan baik pada $\mathrm{pH} 5,5-$ 6,5. Kandungan bahan organik tergolong sedang dengan nilai 2,26\%. Kandungan hara makro nitrogen (N) tergolong sedang dengan nilai $0,36 \%$, hara kalium $(\mathrm{K})$ tergolong sangat tinggi dengan nilai 97,48 ppm, sedangkan hara fosfor $(\mathrm{P})$ tidak terdeteksi nilainya saat pengujian. Menurut Jones (1998) kandungan hara K yang tinggi akan menghambat serapan magnesium $(\mathrm{Mg})$ dan calsium (Ca) sehingga menyebabkan terjadinya defisiensi Mg dan Ca. Soepardi (1979) menyatakan bahwa kelebihan $\mathrm{K}$ menyebabkan pembentukan klorofil menjadi terganggu, hal tersebut disebabkan kadar $\mathrm{Mg}$ didalam daun menjadi menurun karena magnesium merupakan salah satu unsur penyusun klorofil. Kelebihan K menyebabkan $\mathrm{K}$ mengikat $\mathrm{N}$ sehingga tanaman menjadi sulit menyerap $\mathrm{N}$.

Berdasarkan data iklim selama penelitian suhu rata-rata telah cukup untuk memenuhi pertumbuhan talas belitung yaitu $26{ }^{0} \mathrm{C}$. Rata-rata curah hujan optimal untuk talas belitung berkisar 1 400-2 $000 \mathrm{~mm}$ atau berkisar 116-166 $\mathrm{mm}$ bulan -1 yang merata sepanjang tahun (Prohati, 2016). Data curah hujan selama penelitian menunjukkan 
bahwa curah hujan berlebih untuk pertumbuhan talas belitung yaitu $502 \mathrm{~mm}$ bulan $^{-1}$. Penyinaran selama penelitian belum karena hanya 6-7 jam per hari untuk memenuhi pertumbuhan talas belitung. Penyinaran matahari untuk talas belitung minimum 11 jam per hari (Ermayuli, 2011). Kelembaban rata-rata untuk talas belitung menurut Prohati (2016) adalah 50-90\% dan telah sesuai dengan kelembaban rata-rata saat penelitian yaitu $85 \%$. Gulma dominan yang tumbuh di lahan penelitian yaitu Mimosa pigra, Mimosa pudica, Axonopus compressus, Borreria alata.

\section{Persentase Tanaman Hidup}

Perlakuan tunggal jarak tanam, dosis pupuk kalium dan interaksinya tidak menunjukkan pengaruh yang nyata terhadap persentase tanaman hidup. Rata-rata daya tumbuh pada 13 dan 14 MST mendekati 100\% (Tabel 1).

Secara keseluruhan rata-rata persentase tanaman hidup mulai dari pengamatan hingga panen memiliki daya tumbuh yang baik selama di lapangan. Hal tersebut didukung dengan data iklim selama penelitian yang menunjukkan bahwa suhu dan kelembaban telah sesuai untuk pertumbuhan talas belitung. Curah hujan yang tinggi menyebabkan lingkungan tumbuh tanaman menjadi lebih lembab, meskipun kelembaban telah tergolong sesuai akan tetapi hampir mendekati titik kritis kelembaban dapat ditolerir oleh tanaman. Erni et al. (2009) menyatakan curah hujan yang tinggi, fluktuasi suhu dan kelembaban udara yang semakin meningkat mampu menstimulasi pertumbuhan dan perkembangan organisme penggangu tanaman (OPT). Faktor yang menyebabkan persentase tanaman hidup pada perlakuan J2 yang rendah diduga karena jarak antar tanaman yang lebih rapat dibandingkan J1 dan menyebabkan lingkungan di sekitar tanaman menjadi lebih lembab. Perlakuan dosis pupuk K1 juga menunjukkan persentase tanaman hidup yang rendah. Hal tersebut diduga dosis tersebut masih kurang untuk melawan serangan hama penyakit pada tanaman. Fageria et al. (2009) menyatakan hara $\mathrm{K}$ dapat meningkatkan ketahanan tanaman terhadap penyakit. Hal tersebut secara langsung juga berpengaruh terhadap interaksi J2K1 sehingga memiliki persentase tanaman hidup yang paling rendah.

Tabel 1. Pengaruh interaksi perlakuan jarak tanam dan dosis pupuk kalium terhadap persentase tanaman hidup pada 13 dan 14 MST

\begin{tabular}{|c|c|c|c|c|}
\hline \multirow{3}{*}{$\begin{array}{l}\text { Pupuk kalium (K) } \\
\quad\left(\mathrm{kg} \mathrm{ha}^{-1} \mathrm{KCl}\right)\end{array}$} & \multicolumn{4}{|c|}{ Jarak tanam $(\mathrm{m} \times \mathrm{m})$} \\
\hline & \multicolumn{2}{|c|}{$13 \mathrm{MST}$} & \multicolumn{2}{|c|}{$14 \mathrm{MST}$} \\
\hline & $\mathrm{J} 1(1 \times 1)$ & $\mathrm{J} 2(1 \times 0.5)$ & $\mathrm{J} 1(1 \times 1)$ & $\mathrm{J} 2(1 \times 0.5)$ \\
\hline K1 (100) & 100 & 98,8 & 100 & 98,8 \\
\hline K2 (200) & 100 & 100 & 100 & 100 \\
\hline
\end{tabular}

\section{Tinggi Tanaman}

Hasil pengamatan menunjukkan bahwa perlakuan jarak tanam memberikan pengaruh nyata terhadap tinggi tanaman pada $4 \mathrm{MST}, 9$ MST, 12 MST hingga 20 MST. Perlakuan dosis pupuk $\mathrm{K}$ dan interaksi antara jarak tanam dan dosis pupuk $\mathrm{K}$ tidak memberikan pengaruh yang nyata terhadap tinggi tanaman. Pengaruh perlakuan jarak tanam terhadap tinggi tanaman pada setiap MST menunjukkan bahwa perlakuan J1 memiliki rata-rata tinggi tanaman lebih tinggi dibanding perlakuan jarak tanam J2 (Tabel 2).

Tabel 2. Pengaruh perlakuan jarak tanam, dosis pupuk kalium terhadap tinggi tanaman

\begin{tabular}{|c|c|c|c|c|c|c|}
\hline \multirow{3}{*}{ Perlakuan } & \multicolumn{6}{|c|}{ Tinggi tanaman $(\mathrm{cm})$} \\
\hline & 4 & 9 & 14 & 16 & 18 & 20 \\
\hline & \multicolumn{6}{|c|}{ MST } \\
\hline \multicolumn{7}{|l|}{ Jarak tanam $(\mathrm{J})$} \\
\hline $1 \mathrm{~m} \times 1 \mathrm{~m}(\mathrm{~J} 1)$ & $23.19 a$ & $37.08 \mathrm{a}$ & $44.13 a$ & $47.59 a$ & $48.68 \mathrm{a}$ & $47.66 \mathrm{a}$ \\
\hline $1 \mathrm{~m} \times 0.5 \mathrm{~m}(\mathrm{~J} 2)$ & $22.15 b$ & $34.49 \mathrm{~b}$ & $32.99 \mathrm{~b}$ & $35.06 \mathrm{~b}$ & $33.88 \mathrm{~b}$ & $32.26 \mathrm{~b}$ \\
\hline \multicolumn{7}{|l|}{ Pupuk kalium (K) } \\
\hline $100 \mathrm{~kg} \mathrm{ha}^{-1} \mathrm{KCL}(\mathrm{K} 1)$ & 23.11 & 35.50 & 37.39 & 39.16 & 39.30 & 36.75 \\
\hline $150 \mathrm{~kg} \mathrm{ha}^{-1} \mathrm{KCL}(\mathrm{K} 2)$ & 22.23 & 36.06 & 39.74 & 43.49 & 43.26 & 43.18 \\
\hline
\end{tabular}


Penggunaan jarak tanam yang rapat akan menyebabkan antara daun sesama tanaman saling menutupi dan berpengaruh terhadap pertumbuhan tanaman dengan bentuk tanaman yang tinggi memanjang karena bersaing dalam mendapatkan cahaya (Nurlaili, 2010). Menurut Lakitan (1996) laju pertumbuhan tinggi tanaman lebih terpacu apabila tanaman ditanam pada tempat dengan intensitas cahaya yang rendah. Hasil penelitian ini menunjukkan bahwa jarak tanam yang lebih luas menghasilkan rata-rata tinggi tanaman yang lebih tinggi. Hal tersebut diduga disebabkan pada jarak tanam yang lebih lebar populasi lebih sedikit sehingga kompetisi antar tanaman menjadi lebih kecil. Kompetisi antar tanaman yang lebih kecil memungkinkan tanaman menjadi lebih banyak dalam mendapatkan unsur hara dan air dan mempengaruhi pertumbuhan tanaman menjadi lebih tinggi. Hal tersebut sesuai dengan pernyataan Guinn (1976) jarak tanam yang rapat akan menyebabkan banyak kompetisi unsur hara dan air. Mawazin dan Suhaendi (2008) juga menyatakan jarak tanam akan mempengaruhi efektivitas penyerapan unsur hara sehingga jarak tanam yang semakin rapat maka populasi tanaman per satuan luas juga akan semakin banyak sehingga persaingan hara antar tanaman menjadi semakin ketat. Hasil analisis tanah pada penelitian juga menunjukkan bahwa jumlah $\mathrm{K}$ pada J1 lebih tinggi dibandingkan J2. Hal tersebut diduga juga berpengaruh terhadap pertumbuhan tinggi tanaman. Fageria et al. (2009) menyatakan hara K dapat meningkatkan ketahanan tanaman terhadap penyakit. Tanaman pada J1 yang lebih tahan terhadap serangan hama dan penyakit menghasilkan pertumbuhan yang lebih baik dan menghasilkan tinggi tanaman yang lebih tinggi.

\section{Diameter batang}

Hasil pengamatan menunjukkan bahwa perlakuan jarak tanam memberikan pengaruh yang sangat nyata terhadap diameter batang pada 11 MST, 12 MST, 13 MST, 14 MST, 15 MST, 19 MST dan berpengaruh nyata pada 9 MST, 10 MST, 15 MST, 16 MST, 18 MST dan 20 MST. Perlakuan dosis pupuk K menunjukkan pengaruh nyata terhadap diameter batang pada 14 MST dan 15 MST sedangkan interaksi antara perlakuan jarak tanam dan dosis pupuk $\mathrm{K}$ tidak menunjukkan pengaruh yang nyata terhadap diameter batang.. Pengaruh perlakuan dosis pupuk K pada 14 MST dan 15 MST menunjukkan bahwa perlakuan dosis pupuk K2 memiliki rata-rata diameter batang lebih besar dibandingkan perlakuan K1 (Tabel 3).

Tabel 3. Pengaruh perlakuan jarak tanam dan dosis pupuk kalium terhadap diameter batang

\begin{tabular}{|c|c|c|c|c|c|c|c|}
\hline \multirow{3}{*}{ Perlakuan } & \multicolumn{7}{|c|}{ Diameter batang $(\mathrm{cm})$} \\
\hline & 9 & 10 & 12 & 14 & 15 & 18 & 20 \\
\hline & \multicolumn{7}{|c|}{ MST } \\
\hline \multicolumn{8}{|l|}{ Jarak tanam $(\mathrm{J})$} \\
\hline $1 \mathrm{~m} \times 1 \mathrm{~m}(\mathrm{~J} 1)$ & $3.24 \mathrm{a}$ & $3.02 \mathrm{a}$ & $3.75 \mathrm{a}$ & $3.56 \mathrm{a}$ & $3.79 \mathrm{a}$ & $3.73 \mathrm{a}$ & $3.77 \mathrm{a}$ \\
\hline $1 \mathrm{~m} \times 0.5 \mathrm{~m}(\mathrm{~J} 2)$ & $2.60 b$ & $2.23 b$ & $2.31 b$ & $2.04 b$ & $2.15 b$ & $2.09 \mathrm{~b}$ & $2.12 b$ \\
\hline \multicolumn{8}{|l|}{ Pupuk kalium (K) } \\
\hline $100 \mathrm{~kg} \mathrm{ha}^{-1} \mathrm{KCL}(\mathrm{K} 1)$ & 2.80 & 2.56 & 2.91 & $2.48 b$ & $2.66 \mathrm{~b}$ & 2.55 & 2.59 \\
\hline $150 \mathrm{~kg} \mathrm{ha}^{-1} \mathrm{KCL}(\mathrm{K} 2)$ & 3.04 & 2.68 & 3.14 & $3.11 \mathrm{a}$ & $3.28 \mathrm{a}$ & 3.27 & 3.30 \\
\hline
\end{tabular}

Hasil penelitian ini menunjukkan bahwa perlakuan jarak tanam yang lebih lebar (J1) cenderung menghasilkan diameter batang tanaman yang lebih besar. Hal tersebut sesuai dengan pernyataan Marjenah (2006) bahwa tanaman yang ditanam pada jarak tanam yang lebih lebar mendapatkan cahaya yang lebih banyak karena mempunyai ruang tumbuh yang lebih luas. Pada saat tanaman mendapat cukup cahaya untuk aktivitas fisiologisnya, tumbuhan cenderung melakukan pertumbuhan kesamping (diameter). Hasil penelitian juga menunjukkan bahwa perlakuan dosis pupuk kalium yang lebih tinggi (K2) memiliki rata-rata diameter batang yang lebih besar. Bel dan Rahmania (2001) menyatakan bahwa pertumbuhan tanaman berkorelasi dengan penambahan konsentrasi $\mathrm{K}$ pada daerah pembesaran. Semakin tinggi konsentrasi unsur hara $\mathrm{K}$ maka lingkar batang semakin besar. Interaksi antara perlakuan jarak tanam dan dosis pupuk tidak menunjukkan pengaruh yang nyata terhadap diameter batang. Hal ini diduga disebabkan faktor lingkungan yang ada di sekitar tanaman. Hama dan penyakit menyebabkan tanaman merana sehingga kurang efektif dalam memanfaatkan cahaya, air dan unsur hara yang tersedia. Umur tanaman yang masih sangat muda juga merupakan salah satu faktor tidak terlihat interaksi antara pelakuan jarak tanam dan dosis pupuk K. Tanaman ini dipanen lebih cepat yaitu pada umur 5 bulan dari umur seharusnya yaitu 10-12 bulan.

\section{Jumlah daun hijau}

Hasil pengamatan menunjukkan bahwa perlakuan jarak tanam memberikan pengaruh yang sangat nyata terhadap jumlah daun hijau 
pada 13 MST, 16 MST, 20 MST dan berpengaruh nyata pada 7 MST, 9 MST, 10 MST, 14 MST dan 20 MST. Perlakuan dosis pupuk kalium dan interaksinya tidak menunjukkan pengaruh yang nyata terhadap jumlah daun hijau. Pengaruh perlakuan jarak tanam terhadap jumlah daun hijau menunjukkan bahwa perlakuan J1 memiliki ratarata jumlah daun hijau lebih banyak dibandingkan perlakuan J2 (Tabel 4).

Tabel 4. Pengaruh perlakuan jarak tanam dan dosis pupuk kalium terhadap jumlah daun hijau

\begin{tabular}{lccccccc}
\hline \multicolumn{1}{c}{ Perlakuan } & \multicolumn{7}{c}{ Jumlah daun hijau (n) } \\
\cline { 2 - 8 } & 7 & 9 & 11 & $\begin{array}{c}14 \\
\text { MST }\end{array}$ & 16 & 17 & 20 \\
\hline Jarak tanam (J) & $3.36 \mathrm{a}$ & $3.60 \mathrm{a}$ & $3.60 \mathrm{a}$ & $3.33 \mathrm{a}$ & $3.20 \mathrm{a}$ & $3.16 \mathrm{a}$ & $2.80 \mathrm{a}$ \\
$1 \mathrm{~m} \mathrm{x} \mathrm{1} \mathrm{m} \mathrm{(J1)}$ & $3.00 \mathrm{~b}$ & $2.70 \mathrm{~b}$ & $2.36 \mathrm{~b}$ & $2.16 \mathrm{~b}$ & $2.03 \mathrm{~b}$ & $2.26 \mathrm{~b}$ & $2.20 \mathrm{~b}$ \\
$1 \mathrm{~m} \mathrm{x} \mathrm{0,5} \mathrm{m} \mathrm{(J2)}$ & & & & & & & \\
Pupuk kalium (K) & 3.00 & 3.03 & 2.80 & 2.43 & 2.33 & 2.63 & 2.36 \\
$100 \mathrm{~kg} \mathrm{ha}^{-1} \mathrm{KCL}(\mathrm{K} 1)$ & 3.36 & 3.26 & 3.16 & 3.06 & 2.90 & 2.80 & 2.63 \\
$150 \mathrm{~kg} \mathrm{ha}^{-1} \mathrm{KCL}(\mathrm{K} 2)$ &
\end{tabular}

Keterangan: Angka yang diikuti huruf yang berbeda pada kolom yang sama menunjukkan berbeda nyata pada uji DMRT taraf 5\%. MST: minggu setelah tanam

Hasil penelitian menunjukkan bahwa perlakuan jarak tanam yang lebih rapat cenderung menurunkan rata-rata jumlah daun hijau. Hal tersebut sesuai dengan pernyataan Guinn (1976) yang menyatakan bahwa jarak tanam yang rapat akan menyebabkan banyak kompetisi cahaya matahari, unsur hara dan air sehingga menurunkan jumlah daun. Hasil penelitian juga menunjukkan bahwa perlakuan dosis pupuk $\mathrm{K}$ dan interaksinya tidak menunjukkan pengaruh yang nyata terhadap jumlah daun hijau. Hal tersebut diduga disebabkan oleh kadar $\mathrm{K}$ tersedia yang sangat tinggi di dalam tanah sebelum penanaman . Gardner et al. (1985) menyatakan bahwa semakin besar jumlah $\mathrm{K}$ tersedia maka akan semakin besar pula jumlah K yang diserap oleh tanaman. Kecenderungan ini disebut konsumsi yang berlebihan (luxury consumption) karena serapan yang besar pada tanaman tidak diikuti oleh peningkatan pertumbuhan. Semakin besar kadar hara $\mathrm{K}$ di dalam tanah diduga mempengaruhi pertumbuhan jumlah daun hijau sehingga tidak menunjukkan pengaruh yang nyata. Hara $\mathrm{K}$ bersifat mobil atau mudah bergerak di dalam tanah (Jones et al., 1991). Tisdale et al. (1990) juga menyatakan pada $\mathrm{pH}$ yang tergolong masam hara $\mathrm{K}$ akan mudah hilang karena tercuci. Berdasarkan hal tersebut hara $\mathrm{K}$ diduga banyak tercuci pada tanah. Hal tersebut didukung oleh hasil analisis tanah pada pada penelitian ini tergolong masam, curah hujan yang berlebih selama penelitian dan kondisi lahan penelitian yang tergolong miring diduga kuat menyebabkan hara $\mathrm{K}$ menjadi tercuci. Hal tersebut menyebabkan perlakuan pupuk $\mathrm{K}$ dan interaksinya tidak menunjukkan pengaruh yang nyata terhadap pertumbuhan jumlah daun hijau. Samadi (1997) menyatakan unsur K diperlukan tanaman untuk pembentukan karbohidrat didalam umbi, memberi kekuatan pada daun, akan tetapi pengaruhnya terhadap pertumbuhan vegetatif tanaman tidak begitu nyata. Jumlah daun kuning

Hasil pengamatan menunjukkan bahwa perlakuan jarak tanam memberikan pengaruh yang sangat nyata terhadap jumlah daun kuning pada 9 MST dan berpengaruh nyata pada 14 MST. Perlakuan dosis pupuk $\mathrm{K}$ menunjukkan pengaruh nyata terhadap jumlah daun hijau pada 15 MST dan 17 MST sedangkan interaksi antara perlakuan jarak tanam dan dosis pupuk $\mathrm{K}$ menunjukkan pengaruh sangat nyata pada 17 MST. Pengaruh perlakuan jarak tanam terhadap jumlah daun kuning menunjukkan bahwa perlakuan jarak tanam tidak menunjukkan hasil jarak tanam mana yang menghasilkan rata-rata jumlah daun kuning terbanyak karena data tidak konsisten. Pengaruh perlakuan dosis pupuk K menunjukkan bahwa dosis pupuk K2 memiliki rata-rata jumlah daun kuning lebih banyak dibandingkan K1 (Tabel 5). Pengaruh interaksi J1K1 memberikan nilai rata-rata jumlah daun kuning terbanyak yaitu 1,46 daun, sedangkan interaksi J2K1 memberikan nilai rata-rata jumlah daun kuning paling sedikit yaitu 0,73 daun (Tabel 6). 
Tabel 5. Pengaruh perlakuan jarak tanam dan dosis pupuk kalium terhadap jumlah daun kuning

\begin{tabular}{|c|c|c|c|c|}
\hline \multirow{3}{*}{ Perlakuan } & \multicolumn{4}{|c|}{${ }^{1)}$ Jumlah daun kuning (n) } \\
\hline & 9 & 14 & 15 & 17 \\
\hline & \multicolumn{4}{|c|}{ MST } \\
\hline \multicolumn{5}{|l|}{ Jarak tanam $(\mathrm{J})$} \\
\hline $1 \mathrm{~m} \times 1 \mathrm{~m}(\mathrm{~J} 1)$ & $0.36 \mathrm{~b}$ & $0.16 \mathrm{a}$ & 0.70 & 1.36 \\
\hline $1 \mathrm{~m} \times 0.5$ m (J2) & $0.83 \mathrm{a}$ & $0.06 \mathrm{~b}$ & 0.53 & 1.06 \\
\hline \multicolumn{5}{|l|}{ Pupuk kalium (K) } \\
\hline $100 \mathrm{~kg} \mathrm{ha}^{-1} \mathrm{KCL}(\mathrm{K} 1)$ & 0.56 & 0.10 & $0.43 b$ & $1.10 \mathrm{~b}$ \\
\hline $150 \mathrm{~kg} \mathrm{ha}^{-1} \mathrm{KCL}(\mathrm{K} 2)$ & 0.63 & 0.13 & $0.80 \mathrm{a}$ & $1.33 \mathrm{a}$ \\
\hline
\end{tabular}

Keterangan: Angka yang diikuti huruf yang berbeda pada kolom yang sama menunjukkan berbeda nyata pada uji DMRT taraf 5\%. MST: minggu setelah tanam, ${ }^{1}$ : sebelum dianalisa data ditransformasi menggunakan $\sqrt{ } \mathrm{x}+0,5$.

Tabel 7. Pengaruh interaksi perlakuan jarak tanam dan dosis pupuk kalium terhadap jumlah daun kuning pada 17 MST

\begin{tabular}{|c|c|c|}
\hline \multirow{3}{*}{ Pupuk kalium (K) } & \multicolumn{2}{|c|}{${ }^{1)}$ Jumlah daun kuning } \\
\hline & \multicolumn{2}{|c|}{ Jarak tanam $(\mathrm{J})$} \\
\hline & $1 \times 1(\mathrm{~J} 1)$ & $1 \times 0.5(\mathrm{~J} 2)$ \\
\hline K1 & $1.46 \mathrm{a}$ & $0.73 b$ \\
\hline $\mathrm{K} 2$ & $1.26 \mathrm{a}$ & $1.40 \mathrm{a}$ \\
\hline
\end{tabular}

Hasil penelitian menunjukkan bahwa perlakuan jarak tanam bukan faktor tunggal yang mempengaruhi jumlah daun kuning. Pengamatan selama penelitian daun kuning dipengaruhi oleh jumlah daun hijau. Daun hijau pada tanaman talas belitung paling banyak berjumlah 5 daun dan pada daun ke 6 daun akan berubah menjadi kuning. Serangan hama dan penyakit juga mempengaruhi jumlah daun kuning. Pada tanaman yang terserang hama dan penyakit maka jumlah daun pada setiap tanaman juga berkurang dan hal itu juga mempengaruhi jumlah daun kuning yang dihasilkan. Hasil penelitian juga menunjukkan bahwa dosis $\mathrm{K}$ yang lebih tinggi (K2) menunjukkan peningkatan jumlah daun kuning. Hal tersebut disebabkan kandungan $\mathrm{K}$ pada tanah yang sangat tinggi dan ditambah dosis $\mathrm{K}$ yang lebih tinggi menyebabkan pertumbuhan daun kuning meningkat. Kelebihan $\mathrm{K}$ menyebabkan kadar $\mathrm{Mg}$ di dalam daun menurun sehingga pembentukan klorofil atau zat hijau daun terganggu karena $\mathrm{Mg}$ merupakan salah satu unsur penyusun klorofil (Soepardi, 1979). Selain itu jumlah K yang tinggi juga menyebabkan $\mathrm{K}$ menghambat serapan $\mathrm{N}$. Nitrogen merupakan komponen penyusun klorofil atau zat hijau daun yang berperan dalam proses fotosintesis (Samekto, 2008). Hal tersebut juga didukung oleh hasil penelitian bahwa semakin tinggi dosis $\mathrm{K}$ yang diberikan maka unsur hara $\mathrm{N}$ semakin menurun (Tabel 7). Penurunan unsur hara $\mathrm{Mg}$ dan $\mathrm{N}$ pada daun diduga menjadi penyebab daun menjadi kuning. Jarak tanam yang lebih rapat pada hasil interaksi juga menunjukkan bahwa jumlah daun kuning yang diperoleh lebih sedikit. Hal tersebut disebabkan pada jarak tanam yang lebih rapat tanaman lebih berkompetisi dalam mendapatkan unsur hara, air dan cahaya sehingga daun yang dihasilkan juga lebih sedikit.

Tabel 7. Pengaruh perlakuan jarak tanam dan dosis pupuk kalium terhadap kadar N, P dan K dalam daun

\begin{tabular}{lccc}
\hline \multirow{2}{*}{ Perlakuan } & \multicolumn{3}{c}{ Kadar hara N, P dan K dalam daun (\%) } \\
\cline { 2 - 4 } & $\mathrm{N}$ & $\mathrm{P}$ & $\mathrm{K}$ \\
\hline Jarak tanam (J) & 3.36 & 0.25 & 2.08 \\
$1 \mathrm{~m} \mathrm{x} \mathrm{1} \mathrm{m} \mathrm{(J1)}$ & 3.16 & 0.24 & 2.26 \\
$1 \mathrm{~m} \mathrm{x} \mathrm{0,5} \mathrm{m} \mathrm{(J2)}$ & & & \\
Pupuk kalium (K) & $3.39 \mathrm{a}$ & 0.25 & 2.26 \\
$100 \mathrm{~kg} \mathrm{ha}^{-1} \mathrm{KCL}(\mathrm{K} 1)$ & $3.13 \mathrm{~b}$ & 0.24 & 2.09 \\
$150 \mathrm{~kg} \mathrm{ha}^{-1} \mathrm{KCL}(\mathrm{K} 2)$ & Optimum & Optimum & Optimum \\
Status hara & &
\end{tabular}




\section{Kadar hara N, P dan K dalam daun}

Hasil analisis menunjukkan bahwa perlakuan dosis pupuk $\mathrm{K}$ serta interaksinya memberikan pengaruh yang nyata terhadap kadar hara $\mathrm{N}$ dalam daun dan tidak memberikan pengaruh nyata terhadap kadar hara $\mathrm{P}$ dan $\mathrm{K}$ dalam daun. Rata-rata kadar hara $\mathrm{N}$ tertinggi terdapat pada perlakuan dosis pupuk K1 yaitu $3,39 \%$ dan terendah pada perlakuan dosis pupuk K2 yaitu 3,13 \% (Tabel 8). Rata-rata kadar hara N tertinggi terdapat pada interaksi J1K1 dan terendah pada interaksi J1K2 namun tidak berbeda nyata dengan $\mathrm{J} 2 \mathrm{~K} 1$ dan $\mathrm{J} 2 \mathrm{~K} 2$ (Tabel 8).

Tabel 8. Pengaruh interaksi perlakuan jarak tanam dan dosis pupuk kalium terhadap kadar $\mathrm{N}$ dalam daun

\begin{tabular}{lcc}
\hline \multirow{2}{*}{ Pupuk kalium $(\mathrm{K})$} & \multicolumn{3}{c}{ Kadar N dalam daun $(\%)$} \\
\cline { 2 - 3 } & $1 \times 1(\mathrm{~J} 1)$ & \multicolumn{2}{c}{ Jarak tanam $(\mathrm{J})$} \\
\cline { 2 - 3 } & $3,65 \mathrm{a}$ & $3,13 \mathrm{~b}$ \\
\hline $100 \mathrm{~kg} \mathrm{ha}^{-1} \mathrm{KCl}(\mathrm{K} 1)$ & $3,07 \mathrm{~b}$ & $3,20 \mathrm{~b}$ \\
$200 \mathrm{~kg} \mathrm{ha}^{-1} \mathrm{KCl}(\mathrm{K} 2)$ & $\mathrm{J} 2)$ \\
\hline
\end{tabular}

Keterangan: Angka yang diikuti huruf yang berbeda menunjukkan berbeda nyata pada uji DMRT taraf 5\%. J1: jarak tanam $1 \mathrm{~m} \times 1$ $\mathrm{m}, \mathrm{J} 2$ : jarak tanam $1 \mathrm{~m} \times 0,5 \mathrm{~m}, \mathrm{~K} 1$ : pupuk $100 \mathrm{~kg} \mathrm{ha}^{-1} \mathrm{KCL}, \mathrm{K} 2$ : pupuk $150 \mathrm{~kg} \mathrm{ha}^{-1} \mathrm{KCl}$

Hasil analisis tanaman pada daun menunjukkan bahwa semakin tinggi penggunakan pupuk $\mathrm{K}$ cenderung menurunkan kadar hara $\mathrm{N}$ dalam daun. Hal tersebut kemungkinan disebabkan pupuk $\mathrm{N}$ tidak terserap dengan baik oleh tanaman pada penggunanan pupuk $\mathrm{K}$ yang berlebihan. Menurut Hartt dan Burr (1967) hara N dan $\mathrm{K}$ berperan dalam proses sintesis protein, asam amino, gula, dan aktivitas enzim fotosintesis. Dalam proses metabolisme tanaman, hara $\mathrm{N}$ banyak berperan dalam regulasi ekspresi gen penghasil beberapa protein yaitu salah satunya protein pengendali pertumbuhan vegetatif dan klorofil a atau b (Sugiharto et al., 1992). Hara $\mathrm{K}$ mengendalikan aktivitas lebih dari 60 enzim yang umumnya mempunyai peran penting dalam proses metabolisme tanaman (Marschner, 1986). Salisbury dan Ross (1992) juga menyatakan bahwa hara $\mathrm{K}$ mempengaruhi status dan aktivitas beberapa enzim pengendali tekanan osmotik, transportasi asimilat, sintesis protein dan pati, perkembangan sel dan pergerakan stomata. Berdasarkan fungsi dari masing-masing hara tersebut disimpulkan bahwa antara hara $\mathrm{N}$ dan $\mathrm{K}$ memiliki hubungan yang saling berkaitan. Sehingga keseimbangan kedua hara tersebut mempengaruhi fungsinya. Hal tersebut juga pengambilan sampel tanaman, dimana jumlah sampel daun yang diambil menjadi terbatas dan urutan daun yang diambil tidak seragam.

Waktu pengambilan sampel tanaman yang tidak tepat waktu yaitu $>2$ minggu juga diduga mempengaruhi hasil analisis daun. Lukman (2007) menyatakan penundaan pengambilan sampel daun dapat menurunkan konsentrasi N,P dan $\mathrm{K}$ pada daun. Berdasarkan hasil nilai hara pada daun menunjukkan status hara N,P dan $\mathrm{K}$ pada daun tergolong optimum (Tabel 4) artinya unsur hara telah terserap secara optimal oleh tanaman. Curah hujan yang cukup banyak selama diduga menjadi faktor yang menyebabkan saat dosis $\mathrm{K}$ lebih tinggi menurunkan jumlah $\mathrm{N}$ di dalam daun. Kelebihan $\mathrm{K}$ menyebabkan $\mathrm{K}$ menghambat serapan $\mathrm{N}$ sehingga tanaman menjadi sulit menyerap $\mathrm{N}$.

Interaksi perlakuan J1K1 menunjukkan kadar hara $\mathrm{N}$ pada daun paling tinggi. Hasil tersebut menunjukkan bahwa dengan jarak tanam yang lebih lebar dan dosis pupuk $\mathrm{K}$ yang lebih rendah menyebabkan hara $\mathrm{N}$ terserap dengan baik oleh daun. Pada jarak tanam yang lebih lebar populasi tanaman menjadi lebih sedikit sehingga kompetisi hara menjadi lebih kecil. Perlakuan tunggal jarak tanam, dosis pupuk $\mathrm{K}$ serta interaksinya tidak menunjukkan pengaruh yang nyata terhadap hara $\mathrm{P}$ dan $\mathrm{K}$ dalam daun. Idris (1996) menyatakan terdapat 2 hal penting yang perlu diperhatikan dalam analisis daun yaitu keakuratan data analisis daun dan kemampuan dalam menginterpretasikan data tersebut. Keakuratan data analisis ditentukan mulai dari pengambilan sampel jaringan tanaman yang tepat, waktu yang tepat, dan jumlah yang memadai. Kondisi tanaman yang terserang hama dan penyakit menyebabkan tanaman banyak kehilangan daun. Lukman (2007) menyatakan hal tersebut berpengaruh terhadap proses. penelitian menyebabkan air tersedia dan membuat tanah menjadi lembab. Keadaan tersebut tersebut mempengaruhi proses translokasi dan serapan hara tanah sehingga berjalan dengan baik. Hal tersebut didukung oleh kapasitas tukar kation (KTK) selama bulan penelitian berada dalam kondisi sedang.

\section{Produksi Talas Belitung}

Hasil pengamatan menunjukkan bahwa perlakuan jarak tanam memberikan pengaruh nyata terhadap diameter bongkol per tanaman, BB 
dan BK umbi per tanaman, BB dan BK brangkasan per tanaman. Perlakuan dosis pupuk K menunjukkan pengaruh nyata terhadap BB umbi per tanaman sedangkan interaksinya tidak menunjukkan pengaruh yang nyata pada setiap komponen produksi. Pengaruh perlakuan jarak tanam terhadap diameter bongkol, BB umbi, BK umbi, BB brangkasan dan BK brangkasan menunjukkan bahwa perlakuan $\mathrm{J} 1$ memiliki ratarata hasil yang lebih tinggi dibandingkan perlakuan J2. Pengaruh perlakuan dosis pupuk K terhadap BB umbi menunjukkan bahwa perlakuan dosis pupuk K2 memiliki rata-rata BB umbi yang lebih tinggi dibandingkan perlakuan dosis pupuk K1 (Tabel 9).

Tabel 9. Pengaruh perlakuan jarak tanam, dosis pupuk kalium terhadap komponen produksi talas belitung per tanaman

\begin{tabular}{|c|c|c|c|c|c|}
\hline \multirow[b]{2}{*}{ Perlakuan } & \multicolumn{5}{|c|}{ Komponen produksi } \\
\hline & ${ }^{1)}$ Jumlah umbi (n) & $\begin{array}{l}{ }^{1)} \text { Panjang } \\
\text { umbi }(\mathrm{cm})\end{array}$ & $\begin{array}{l}{ }^{1)} \text { Diameter umbi } \\
(\mathrm{cm})\end{array}$ & $\begin{array}{l}\text { Panjang umbi } \\
(\mathrm{cm})\end{array}$ & $\begin{array}{c}\text { Diameter } \\
\text { bongkol } \\
(\mathrm{cm})\end{array}$ \\
\hline \multicolumn{6}{|l|}{ Jarak tanam $(\mathrm{J})$} \\
\hline $1 \mathrm{~m} \times 1 \mathrm{~m}(\mathrm{~J} 1)$ & 6.76 & 9.52 & 1.33 & 7.34 & $3.84 \mathrm{a}$ \\
\hline $1 \mathrm{~m} \times 0.5$ m (J2) & 3.03 & 7.42 & 1.03 & 6.56 & $3.24 \mathrm{~b}$ \\
\hline \multicolumn{6}{|l|}{ Pupuk kalium (K) } \\
\hline $100 \mathrm{~kg} \mathrm{ha}^{-1} \mathrm{KCL}(\mathrm{K} 1)$ & 3.90 & 8.38 & 1.13 & 6.81 & 3.43 \\
\hline $150 \mathrm{~kg} \mathrm{ha}^{-1} \mathrm{KCL}(\mathrm{K} 2)$ & 5.90 & 1.13 & 1.22 & 7.09 & 3.65 \\
\hline \multirow[b]{2}{*}{ Perlakuan } & \multicolumn{5}{|c|}{ Komponen produksi } \\
\hline & ${ }^{11} \mathrm{BB}$ umbi (g) & $\begin{array}{c}{ }^{1)} \text { BK umbi } \\
(\mathrm{g})\end{array}$ & ${ }^{1)} \mathrm{BB}$ brangkasan (g) & $\begin{array}{c}{ }^{\mathrm{I}} \mathrm{BK} \\
\text { brangkasan }(\mathrm{g})\end{array}$ & $\begin{array}{l}{ }^{1 \mathrm{I}} \text { Indeks } \\
\text { panen (\%) }\end{array}$ \\
\hline \multicolumn{6}{|l|}{ Jarak tanam $(\mathrm{J})$} \\
\hline $1 \mathrm{~m} \times 1 \mathrm{~m}(\mathrm{~J} 1)$ & $136.16 \mathrm{a}$ & $34.16 \mathrm{a}$ & $439.22 \mathrm{a}$ & $49.97 \mathrm{a}$ & 38.57 \\
\hline \multirow{2}{*}{\multicolumn{6}{|c|}{ Pupuk kalium (K) }} \\
\hline & & & & & \\
\hline $100 \mathrm{~kg} \mathrm{ha}^{-1} \mathrm{KCL}(\mathrm{K} 1)$ & $73.99 \mathrm{~b}$ & 19.83 & 231.07 & 28.14 & 35.61 \\
\hline $150 \mathrm{~kg} \mathrm{ha}^{-1} \mathrm{KCL}(\mathrm{K} 2)$ & $127.93 \mathrm{a}$ & 30.23 & 373.98 & 43.70 & 39.10 \\
\hline
\end{tabular}

Keterangan: Angka yang diikuti huruf yang berbeda pada kolom yang sama menunjukkan berbeda nyata pada uji DMRT taraf 5\%. tn: tidak nyata, BB: bobot basah, BK: berat kering, KK: koefisien keragaman, ${ }^{1)}$ : sebelum dianalisa data ditransformasi menggunakan $\sqrt{ } \mathrm{x}+0,5$

Jumlah umbi, panjang umbi, diameter umbi dan panjang bongkol

Hasil penelitian menunjukkan bahwa perlakuan tunggal jarak tanam, dosis pupuk K dan interaksinya tidak memberikan pengaruh yang nyata terhadap jumlah umbi, panjang umbi, diameter umbi dan panjang bongkol. Hal tersebut diduga disebabkan tanaman belum menunjukkan reaksi terhadap perlakuan yang diberikan karena umur tanaman yang masih sangat muda yaitu 5 BST. Menurut Small (2009) talas belitung dapat dipanen pada umur 10-12 bulan setelah penanaman. Pada saat tanaman umur 5 bulan diduga masih lebih aktif dalam memanfaatkan hasil fotosintesis pada pertumbuhan vegetatif sehingga pada pertumbuhan generatif belum terlalu terlihat. Hal tersebut juga ditunjukkan pertumbuhan tinggi tanaman, diameter batang dan jumlah daun yang masih cenderung meningkat setiap minggunya (Tabel 2, 3 dan 4). Menurut Palmer et al. (1969) terdapat dua faktor yang mempengaruhi pembentukan umbi yaitu faktor internal dan faktor eksternal. Faktor internal terdiri atas hormon tumbuh dan metabolisme karbohidrat sedangkan faktor eksternal terdiri atas panjang hari, suhu, kelembaban, dan hara.

Faktor panjang hari diduga menjadi salah satu faktor yang menyebabkan perlakuan tidak menunjukkan pengaruh nyata. Penyinaran matahari selama penelitian rata-rata hanya 5,86 jam hari ${ }^{-1}$ dari yang seharusnya minimum 11 jam untuk pertumbuhan talas (Ermayuli, 2011). Panjang hari berpengaruh terhadap jumlah karbohidrat yang akan dihasilkan tanaman dalam proses fotosintesis. Karbohidrat sangat diperlukan tanaman untuk proses pembentukan umbi pada fase generatif. Selama penelitian tanaman talas juga banyak yang menghasilkan bunga pada bulan April-Juni. Hal tersebut juga diduga mempengaruhi hasil umbi pada tanaman, dimana sebagian hasil fotosintesis menjadi terbagi untuk pertumbuhan bunga. Faktor lingkungan seperti gangguan hama penyakit juga diduga menjadi faktor yang mempengaruhi hasil tidak nyata. Hama dan penyakit yang menyerang tanaman mulai 5 MST menyebabkan tanaman menjadi merana sehingga menghambat pertumbuhan tanaman. 
Diameter bonggol, bobot basah umbi dan bobot kering umbi

Hasil penelitian menunjukkan bahwa jarak tanam yang lebih lebar (J1) cenderung meningkatkan diameter bonggol, BB umbi dan BK umbi. Guiin (1976) menyatakan bahwa jarak tanam yang rapat akan menyebabkan banyak kompetisi cahaya matahari, unsur hara dan air sehingga menurunkan jumlah daun. Penurunan jumlah daun mengakibatkan penurunan efektivitas tanaman dalam melakukan fotosintesis karena cahaya yang diterima menjadi lebih sedikit. Laju fotosintesis berhubungan dengan ketersediaan bahan mentah yaitu air, karbondioksida dan cahaya matahari. Ketersediaan bahan mentah yang cukup akan meningkatkan jumlah karbohidrat yang terbentuk dalam proses fotosintesis. Pada fase generatif, tanaman menggunakan karbohidrat untuk proses pembentukan umbi. Hasil penelitian juga menunjukkan bahwa penggunaan dosis pupuk $\mathrm{K}$ yang lebih tinggi (K2) cenderung meningkatkan BB umbi. Hal tersebut disebabkan tanaman mendapatkan unsur $\mathrm{K}$ yang cukup sehingga mampu membentuk umbi yang besar dan juga meningkatkan bobot umbi. Sreekariyam et al. (2003) juga menyatakan pada tanaman umbi-umbian kebutuhan unsur $\mathrm{K}$ lebih tinggi dari pada unsur N. Hal tersebut diduga menjadi penyebab bahwa dengan penambahan dosis pupuk $\mathrm{K}$ mampu meningkatkan BB umbi.

\section{Samadi (1997) menyatakan hara K} diperlukan tanaman untuk pembentukan karbohidrat didalam umbi, memperbesar umbi dan meningkatkan daya simpan umbi. Perlakuan dosis pupuk $\mathrm{K}$ tidak menunjukkan pengaruh yang nyata terhadap diameter bongkol dan BK umbi. Interaksi antara perlakuan jarak tanam dan dosis pupuk $\mathrm{K}$ juga tidak menunjukkan pengaruh yang nyata terhadap diameter bongkol, BB umbi dan BK umbi. Hal tersebut diduga disebabkan umur tanaman yang masih sangat muda sehingga belum terlalu menunjukkan pengaruh yang nyata. Pada penelitian ini tanaman telah dipanen pada umur 5 BST dari pertumbuhan yang seharusnya yaitu 1012 bulan. Faktor hama penyakit juga diduga menjadi penyebab tanaman belum menunjukkan hasil yang nyata. Pengeringan umbi yang kurang pada saat pengovenan juga diduga menjadi faktor bobot kering umbi belum menunjukkan pengaruh yang nyata. Setiap umbi memiliki ketebalan yang berbeda-beda sehingga pada saat pengovenan tidak seluruh bagian umbi kering dengan sempurna. Penyusunan umbi didalam oven yang terlalu rapat juga diduga faktor yang mempengaruhi bobot kering umbi.

\section{Bobot basah dan bobot kering brangkasan}

Hasil penelitian juga menunjukkan bahwa pada jarak tanam yang lebih lebar cenderung meningkatkan $\mathrm{BB}$ dan $\mathrm{BK}$ brangkasan. Hal tersebut dipengaruhi oleh diameter batang, jumlah daun dan bobot bongkol yang dihasilkan oleh tanaman, karena brangkasan terdiri dari batang, daun dan bongkol. Hal tersebut sesuai dengan hasil pada penelitian ini, dimana pada jarak tanam yang lebih lebar menghasilkan diameter batang yang lebih besar, jumlah daun yang lebih banyak dan diameter bongkol yang lebih besar (Tabel 1,2 dan 5). Marjenah (2006) menyatakan bahwa tanaman yang ditanam pada jarak tanam yang lebih lebar mendapatkan cahaya yang lebih banyak karena mempunyai ruang tumbuh yang lebih luas. Selain faktor cahaya, jarak tanam yang lebih lebar juga akan menyerap unsur hara dan air yang lebih baik karena populasi menjadi lebih sedikit dan kompetisi antar tanaman menjadi lebih kecil.

Perlakuan tunggal dosis pupuk $\mathrm{K}$ dan interaksinya tidak menunjukkan pengaruh yang nyata terhadap $\mathrm{BB}$ dan BK brangkasan. Hal tersebut diduga disebabkan dosis pupuk $\mathrm{K}$ tidak terlalu berpengaruh terhadap pertumbuhan vegetatif tanaman. Samadi (1997) menyatakan unsur $\mathrm{K}$ diperlukan tanaman untuk pembentukan karbohidrat didalam umbi, memberi kekuatan pada daun, akan tetapi pengaruhnya terhadap pertumbuhan vegetatif tanaman tidak begitu nyata. Faktor hama dan penyakit yang menyerang tanaman selama penelitian juga menyebabkan tanaman merana dan mempengaruhi hasil perlakuan. Selain itu faktor pengeringan brangkasan sewaktu dioven juga diduga menjadi faktor BK brangkasan tidak berpengaruh nyata. Ukuran setiap brangkasan yang berbeda-beda menyebabkan tidak seluruh bagian brangkasan kering dengan sempurna. Penyusunan brangkasan didalam oven yang terlalu rapat juga diduga faktor yang menyebabkan pengeringan tidak sempurna dan mempengaruhi BK brangkasan.

\section{Indeks panen}

Hasil penelitian menunjukkan bahwa perlakuan tunggal jarak tanam, dosis pupuk $\mathrm{K}$ dan interaksinya tidak menunjukkan pengaruh yang nyata terhadap indeks panen. Hal tersebut diduga disebabkan tanaman masih terlalu muda saat dipanen sehingga belum menunjukkan hasil yang nyata. Selain itu faktor hama dan penyakit juga mempengaruhi pertumbuhan sehingga menggangu dalam proses metabolisme tanaman. Menurut widodo (1995) indeks panen untuk tanaman talas 
belitung adalah 60-85\%. Berdasarkan hasil penelitian, indeks panen masih tergolong rendah karena berkisar antara 33,84\%-39,76 (Tabel 5). Menurut Fisher (1992) indeks panen yang rendah merupakan indikasi dari adanya persaingan sink. Hasil fotosintat lebih banyak dibagikan pada bagian tajuk tanaman untuk membentuk daun yang baru. Prawinata et al. (1981) juga menyatakan bahwa penurunan indeks panen berarti terjadi penurunan pembentukkan umbi dan peningkatan pertumbuhan bagian vegetatif tanaman.

Rendahnya nilai indeks panen juga diduga karena umur panen yang masih sangat muda sehingga hasil generatif yang diperoleh masih rendah. Selain itu pada umur yang masih sangat muda tanaman diduga sedang giatnya untuk melakukan pertumbuhan vegetatif sehingga hasil fotosintat banyak digunakan untuk hal tersebut. Hasil penelitian juga menunjukkan bahwa perlakuan jarak tanam yang lebih rapat dan perlakuan dosis pupuk $\mathrm{K}$ yang lebih rendah cenderung menurunkan indeks panen (Tabel 9). Hal tersebut disebabkan pada jarak tanam yang lebih rapat menyebabkan tanaman lebih berkompetisi dalam mendapatkan unsur hara, air dan cahaya sehingga berpengaruh terhadap umbi yang dihasilkan sedangkan hara $\mathrm{K}$ dibutuhkan dalam jumlah yang banyak dalam pembentukkan umbi dan translokasi karbohidrat. Hal tersebut yang menyebabkan meskipun hasil analisis tanah $\mathrm{K}$ pada penelitian ini sangat tinggi, tetapi masih tetap meningkatkan indeks panen.

\section{KESIMPULAN}

Jarak tanam $1 \mathrm{~m}$ x $1 \mathrm{~m}$ merupakan jarak tanam terbaik untuk pertumbuhan (tinggi tanaman, diameter batang, jumlah daun hijau) dan produksi talas belitung (diameter bonggol, bobot basah umbi, bobot kering umbi, bobot basah brangkasan dan bobot kering brangkasan). Dosis pupuk $150 \mathrm{~kg} \mathrm{KCL} \mathrm{ha}{ }^{-1}$ merupakan dosis pupuk terbaik untuk pertumbuhan diameter batang dan komponen produksi bobot basah umbi. Interaksi perlakuan jarak tanam $1 \mathrm{~m} \mathrm{x} 1 \mathrm{~m}$ dan dosis pupuk $100 \mathrm{~kg} \mathrm{ha}^{-1} \mathrm{KCL}$ merupakan interaksi terbaik hanya untuk pertumbuhan talas belitung.

\section{DAFTAR PUSTAKA}

Badan Ketahanan Pangan Kementerian Pertanian. 2015. Data statistik ketahanan pangan 2015. [Internet] [Diunggah 2016 Februari 2]. Tersedia pada http://bkp.pertanian.go.id/tinymcpuk/gam bar/file/datastatistikkp2015new.pdf
[Balittanah] Balai Penelitian Tanah. 2009. Analisis Kimia Tanah, Tanaman, Air, dan Pupuk. Balai Penelitian Tanah, Bogor.

Bel, Rahmania, A. A. 2001. Telaah faktor pembatas kacang tanah. J. Ilmu Budidaya Tanaman 1(2):91169. Corwin E.J. 2007. Buku Saku Patofisiologi. Jakarta (ID): Kedokteran EGC.

Ermayuli. 2011. Analisis teknis dan finansial agroindustri skala kecil pada berbagai proses pembuatan keripik talas di Kabupaten Lampung Barat. Tesis. Universitas Lampung, Lampung.

Erni, S., Ramadhani, Runtunuwu, E., Amien, I. 2009. Dampak perubahan iklim terhadap serangan organisme pengganggu tanaman (OPT) serta strategi antisipasi dan adaptasi. Balai Penelitian Agroklimat dan Hidrologi (BALITKLIMAT), Bogor.

Fageria, N. K., Filho, M.P.B., Dacosta, J. H. C. 2009. Potassium in The Use of Nutrients in Crop Plants. London (UK): CRC Press Taylor and Francis Group,

Fisher, N. M., Godworthy, P.R. 1992. Fisiologi Tanaman Budidaya Tropik. Terjemahan Soedharoedjian. Yogyakarta (ID): UGM Press

Gardner F.P., Pearce R.B., Roger L.M. 1991. Fisiologi Tanaman Budidaya. Penerjemah Herawati $S$ dan Subiyanto. Jakarta (ID): Universitas Indonesia

Guinn, G. 1976. Nutritional stress and ethylene evolution tobacco. Crop Sci 1(16): 89-91.

Hartt C.E. dan Burr G.O. 1967. Factors affecting photosynthesis in sugarcane. Proc. Itn. Sugar Cane Technol. 12:625638.

Idris, K. 1996. Kegunaan dan keterbatasan uji tanah dan analisis tanaman bagi pendekatan kebutuhan pupuk. Presentasi Makalah Dalam Pelatihan Pembinaan Uji Tanah dan Analisis Tanaman Kerjasama Antara Fakultas Pertanian IPB Dengan Agriculture Research Management Project; Bogor, 25-27 Desember 1996. 
Indrasti, D. 2004. Pemanfaatan Talas Belitung (Xanthosoma sagittifolium) dalam Pembuatan Cookies. [Skripsi]. Departemen Teknologi Pangan dan Gizi, Fakultas Teknologi Pertanian, Institut Pertanian Bogor.

Jones. 1998. Plant Nutrion Manual. New York (US): CRC press.

Kay, D.E. 1973. Root crops the tropical products institute foreign and common wealth office, London.

Lakitan, B. 1996. Fisiplogi Pertumbuhan dan Perkembangan Tanaman. Jakarta (ID): PT Raja Grafindo Persada

Latifa, I.C., Anggarwulan E. 2009. Nitrogen content, nitrate reductase activity, and biomass of kimpul (Xanthosoma sagittifolium) on shade and nitrogen fertilizer variation. Nusantara Bioscience 1: (65- 71).

Lukman, L. 2007. Diagnosis status hara menggunakan analisis daun untuk menyusun rekomendasi pemupukan pada tanaman manggis (Garcinia mangostana L.). Disertasi. Institut Pertanian Bogor. Bogor.

Marcshner, H. 1986. Mineral Nutrition of Higher Plants. London (UK): Acad Press.

Marinih. 2005. Pembuatan keripik kimpul bumbu balado dengan tingkat pedas yang berbeda. Tugas Akhir. Universitas Negeri Semarang. Semarang.Marjenah. 2006. Hubungan antara jarak tanam dengan tinggi dan diameter tanaman jati (Tectona grandis Linn.f) di Kalimantan Timur. J. Rimba Kalimantan Fakultas Kehutanan Unmul 11(1):21-26.

Mawazin, Suhaendi, H. 2008. Pengaruh jarak tanam terhadap pertumbuhan diameter Shorea parvifolia Dyer. J. Penelitian dan Konservasi Alam 5(4): 381-388.

Nugroho, A.E. 2012. Antidiabetic and antihiperlipidemic effect of andrographis paniculata (burm. F.) Nees and andrographolide in high fructose fat feed rats. Indian Journal of Pharmacology 44(3):377-381.

Nurlaili. 2010. Respon pertumbuhan tanaman jagung (Zea mays L.) dan gulma terhadap berbagai jarak tanam. J. Agronobis. 2(4):1-11.

Palmer, C.E., Smith O.E. 1969. Cytokinin and tuber initiation in the potato (Solanum tuberosum L.). J. Nature 221:279-280.

Plantamor. 2016. Talas belitung. [Internet] [Diunggah 2016 Februari 5] Tersedia pada http://www.plantamor.com/index.pl ant.pdf

Prawinata, W. S., Harran., Tjondronegoro. 1981. Dasar-dasar Fisiologi Tumbuhan. Bogor (ID): Departemen Botani IPB

Prohati. 2016. Xanthosoma nigrum Schott. [Internet] [Diunggah 2016 April 1] Tersedia pada https://www.prohati.com [1 April 2016]

Salisbury, F. B., Ross, C.W. 1992. Plant Physiology. California (US): Wadsworth Publ Co Belmont.

Samadi, B. 1997. Usaha Tani Kentang. Yogyakarta (ID): Kanisius.

Samekto, R. 2008. Pemupukan. Yogyakarta (ID): PT Citra Aji Parama.

Small, E. 2009. Top 100 Food Plants. Canada (CA): NRC Research Press.

Soepardi, G. 1979. Sifat dan Ciri Tanah. Departemen Ilmu-ilmu tanah IPB, Bogor. Sreekariyam dan Thiruvananthapuram. 2003. Nutritional disorders in tropical tuber crops. CTCRI Kerala, India

Sugiharto, B., Burnell, J.N., Sugiyama T. 1992. Cytokinin is required to induce the nitrogen-dependent accumulation of $m$ RNAs for phosphoenolpyruvate carboxylase and carbonic anhydrase in detached maize leaves. Plant Physiol 100:153-156.

Tisdale, S.L., Nelson, W.L., Beaton, J.D. 1990. Soil Fertility and Fertilizer. New York (US): Mc Graw Hill Book Company

Widodo.1995. Kisaran umur panen, produktivitas bahan yang dapat dimakan, dan indeks panen tanaman ubi-ubian. [Internet] [Diunggah pada 2016 September 10]. Tersedia pada http://lsetyobudi.lecture.ub .ac.id.pdf 